\title{
Maternal Residential Proximity to Major Roadways and the Risk of Childhood Acute Leukemia: A Population-Based Case-Control Study in Texas, 1995-2011
}

\author{
Erin C. Peckham-Gregory ${ }^{1,2,+} \oplus$, Minh Ton ${ }^{3,+} \oplus$, Karen R. Rabin ${ }^{1,2}\left(\mathbb{D}\right.$, Heather E. Danysh ${ }^{1,2}$, \\ Michael E. Scheurer ${ }^{1,2}$ and Philip J. Lupo ${ }^{1,2, *}$ \\ 1 Department of Pediatrics, Section of Hematology-Oncology, Baylor College of Medicine, One Baylor Plaza, \\ MS: BCM622, Houston, TX 77030, USA; Erin.Peckham@bcm.edu (E.C.P.-G.); Krrabin@txch.org (K.R.R.); \\ Hdanysh@rti.org (H.E.D.); Scheurer@bcm.edu (M.E.S.) \\ 2 Texas Children's Cancer and Hematology Centers, Texas Children's Hospital, Feigin Center, 1102 Bates St, \\ Houston, TX 77030, USA \\ 3 Department of Economics, Martel College, Rice University, 99 Sunset Blvd, Houston, TX 77005, USA; \\ Mdt3@rice.edu \\ * Correspondence: Philip.Lupo@bcm.edu \\ + These authors contributed equally to this work.
}

Received: 18 April 2019; Accepted: 4 June 2019; Published: 7 June 2019

\begin{abstract}
Acute leukemia is the most common pediatric malignancy. Some studies suggest early-life exposures to air pollution increase risk of childhood leukemia. Therefore, we explored the association between maternal residential proximity to major roadways and risk of acute lymphoblastic leukemia (ALL) and acute myeloid leukemia (AML). Information on cases with acute leukemia $(n=2030)$ was obtained for the period 1995-2011 from the Texas Cancer Registry. Birth certificate controls were frequency matched $(10: 1)$ on birth year $(n=20,300)$. Three residential proximity measures were assessed: (1) distance to nearest major roadway, (2) residence within 500 meters of a major roadway, and (3) roadway density. Multivariate logistic regression was used to generate adjusted odds ratios (aOR) and $95 \%$ confidence intervals (CI). Mothers who lived $\leq 500$ meters to a major roadway were not more likely to have a child who developed ALL (OR = 1.03; 95\% CI: 0.91-1.16) or AML (OR = 0.84; 95\% CI: 0.64-1.11). Mothers who lived in areas characterized by high roadway density were not more likely to have children who developed ALL (OR =1.06, 95\% CI: 0.93-1.20) or AML (OR = 0.83, 95\% CI: 0.61-1.13). Our results do not support the hypothesis that maternal proximity to major roadways is strongly associated with childhood acute leukemia. Future assessments evaluating the role of early-life exposure to environmental factors on acute leukemia risk should explore novel methods for directly measuring exposures during relevant periods of development.
\end{abstract}

Keywords: epidemiology; acute leukemia; traffic-related air pollution; Texas Cancer Registry

\section{Introduction}

Acute leukemia is the most common childhood cancer in the United States and consists of two main subtypes: acute lymphoblastic leukemia (ALL; 73\% of cases ages 0-19 years) and acute myeloid leukemia (AML; 18\% of cases ages 0-19 years) [1]. Due to advances in therapy, 5-year survival for those diagnosed with acute leukemia is approaching 90\% [2-4]. However, survivors often face chronic health conditions as a consequence of their therapy, including diabetes mellitus, cardiovascular disease, and neurocognitive deficits [5,6]. Additionally, the incidence of childhood leukemia has been steadily 
increasing since the 1970s [7,8]. Despite this, very little is known about the causes of acute leukemia, which severely limits prevention and surveillance efforts. In fact, outside of some confirmed risk factors, like cancer predisposition syndromes and exposure to ionizing radiation, over $90 \%$ of cases are of unknown etiology [9].

There are growing public health concerns over the role of ambient air pollution exposure on the risk of developing cancer, both in children and adults [10-12]. This is in part due to known and suspected carcinogenic compounds (e.g., benzene) that are present in motor vehicle emissions [13]. Additionally, several studies have established that those who live near major roadways or areas of high traffic density have higher levels of air pollution exposure compared to those who do not live near major roadways [13-15]. Several proximity measures have been used to study the association between distance to traffic and risk of cancers, including leukemia [16,17]. These distance to traffic measures include distance to nearest major roadway, buffer distances to major roadways, and measures of roadway density (total $\mathrm{km}$ of roads within a buffer) and/or vehicle density [18-20]. Studies have suggested that the closer one lives in proximity to a major roadway, the greater the increase in risk of developing cancer and other comorbidities [21-23]. This is notable as approximately $40 \%$ of individuals in the United States live near a major roadway, and this proportion continues to grow [13].

Some studies have suggested that exposure to motor vehicle emissions is associated with the risk of childhood cancer, including acute leukemia [24-27]. However, to date, results have been equivocal, which in part may be due to differences in exposure levels across geographic regions, exposure assessment methods, small sample sizes, and case inclusion criteria. Because of the increasing incidence of acute leukemia, the growing proportion of the population living in areas characterized by higher levels of ambient air pollution, and inconclusive results in previous assessments, we leveraged one of the largest and most diverse population-based cancer registries in the world in a geographical region characterized by high and variable levels of air pollution to evaluate the role of early-life exposure to ambient air pollution on the risk of developing acute leukemia.

\section{Materials and Methods}

\subsection{Study Design and Population}

To assess the association between maternal residential proximity to major roadways and risk of childhood leukemia, we conducted a population-based case-control study. Information on cases was obtained from the Texas Cancer Registry (TCR), a statewide population-based cancer registry administered by the Texas Department of State Health Services (TX DSHS), which was Gold certified by the North American Association of Central Cancer Registries during the study period. Specifically, the TCR identified children born in Texas between 1 January 1995 and 31 December 2011 who were diagnosed with an acute leukemia before 17 years of age during the same period. We used the International Classification of Childhood Cancer, Third Edition (ICCC-3) to define the acute leukemia subtypes: ALL (ICCC-3 group Ia) and AML (ICCC-3 group Ib) [28]. Only cases diagnosed with acute leukemia as their first primary malignancy were included. For each case, the TCR also provided information on age at the time of diagnosis and used probabilistic linkage to link the cancer registry record to Texas birth certificates.

Control subjects were randomly selected among the birth certificate records of those who were both born in Texas during the same period as cases (1995-2011) and were confirmed not to be included in the TCR. Controls were frequency matched to cases on birth year at a ratio of ten control subjects for every acute leukemia case. For all study subjects, we obtained the geocoded address of the maternal residence at the time of delivery (i.e., at the time of the child's birth), as well as other child- and maternal-related information, from the birth certificate records. 


\subsection{Exposure Assessment}

We determined maternal residential proximity to major roadways using the Texas roadway network StratMap. StratMap was obtained from the Texas National Resources Information System, which maintains the largest collection of geographic data for Texas [29]. In assessing exposure to traffic-related air pollution, we utilized three proxy measures based on maternal residential proximity to major roadways, which are described in detail below: (1) continuous distance of the residence to the nearest major roadway, (2) the presence of a major roadway within a 500 meter $(\mathrm{m})$ radius of the residence, and (3) the density of major roadways within a $500 \mathrm{~m}$ radius of the residence [19]. We selected a buffer of $500 \mathrm{~m}$, as the area of $500 \mathrm{~m}$ adjacent to a major roadway has been found to have the highest concentration of primary air pollutants from traffic emissions and was designated as a buffer region to assess exposure to air pollution [13]. Roadways defined by the U.S. Census Bureau as interstate, state, county, or toll highways (with an A1, A2, or A3 Feature Class Code) were designated as a major roadway [30]. The maternal residential address listed on each subject's birth certificate was geocoded by the TX DSHS Center for Health Statistics. The longitude and latitude data points from the geocoded addresses established residential location and distance to major roadways.

A geographic information systems (GIS) approach was used to assess exposure and geocode street addresses according to 2007 Tiger/Line files [30]. ArcGIS (version 10.0, Environmental Systems Research Institute Inc., Redlands, CA, USA) was used for spatial analyses. We used the Euclidian distance as the distance of the maternal residence to the nearest side of the closest major roadway. This distance was calculated as a continuous measure in meters. Buffer analyses consisted of determining if a major roadway was within a $500 \mathrm{~m}$ radius from maternal residence. Exposure was determined based on the presence or absence of a major roadway within the $500 \mathrm{~m}$ radius around the maternal residence. Roadway density was determined by summing all major roadway segments $(\mathrm{km})$ that fell within the $500 \mathrm{~m}$ radius of the maternal residence and then modeled as a categorical variable. In other words, roadway density refers to the actual amount of $\mathrm{km}$ of major roadway segments within the $500 \mathrm{~m}$ radius of maternal residence. The "low roadway density" category included mothers living outside the $500 \mathrm{~m}$ buffer radius from the nearest major roadway, while mothers residing within $500 \mathrm{~m}$ of a major roadway were defined as residing in an area with "medium roadway density" or "high roadway density" based on the total length of major roadway within the $500 \mathrm{~m}$ buffer. Consistent with previous studies [19,31], the cutoff between medium and high density $(2.11 \mathrm{~km})$ was determined using the median split of the distribution of roadway density among the control subjects living within $500 \mathrm{~m}$ of a major roadway.

\subsection{Covariate Selection}

Covariates selected for the current analysis included child's sex, age at diagnosis, season of birth, gestational size, term of birth ( $<37$ weeks, $37-40,41-42$, and $\geq 42)$, maternal self-reported race/ethnicity (non-Hispanic white, non-Hispanic black, Hispanic, non-Hispanic other), maternal age at time of delivery $(<25,25-30,31-35$, and $\geq 35$ years), maternal education ( $<$ high school, high school, or $>$ high school), urban versus rural status of residence, and area-level poverty [32-39]. We determined season of birth by categorizing every child's birth date as spring, summer, fall, or winter based on solstice and equinox dates. The date of onset of last menstrual period (LMP) and the clinical estimate of gestation in weeks were obtained from birth certificates for cases and controls. For most births, gestational age was established using the LMP $[40,41]$. Based on previous literature, we utilized the clinical estimate as a substitute for LMP if the LMP date was missing or if the absolute difference between the LMP date and clinical estimate was greater than 14 days [41-43]. The birth was excluded from analyses of birth term or size-for-gestational-age if both the LMP date and the clinical estimate were missing. Births were categorized as small-for-gestational-age if the birth weight was $<10$ th percentile for their gestational age or large-for-gestational-age if the birth weight was $>90$ th percentile for their gestational age. The 2009-2010 U.S. live birth data stratified by infant sex provided data for the gestational estimates and percentiles [44]. 
Information on covariates was obtained from the child's birth certificate. Additionally, area-level poverty was used as a surrogate for socioeconomic status (SES). We obtained information from the 2000 US Census on the proportion of households with an income lower than the poverty level in a census tract (a small statistical subdivision of a county designed to represent a relatively homogenous group of approximately 1200 to 8000 people) [45]. Census tracts where $\geq 15 \%$ of households had an income above the poverty level were classified as a high area-level poverty region while census tracts where $<15 \%$ of households had an annual income below the poverty level were classified as a low area-level poverty region.

\subsection{Statistical Analysis}

We abstracted descriptive statistics on child and maternal demographic characteristics along with area-level factors, such as poverty and urban status, for both cases and controls. The distribution of the exposure (e.g., means and frequencies) among cases and controls was calculated for each of the residential proximity measures. $p$-values comparing variables between cases and controls were generated through chi-squared tests for categorical variables or t-tests for continuous variables. Multivariate unconditional logistic regression was used to assess the association between maternal residential proximity to major roadways and each acute leukemia subtype. We conducted these analyses overall (ages $0-16$ years) and among those $\geq 1$ to $\leq 5$ years of age at diagnosis and less than one year of age at diagnosis to reflect differences in cytogenetic profiles among younger cases [46,47], as well as the potential for stronger perinatal exposure effects among those diagnosed earlier in life [25]. We generated unadjusted and adjusted odds ratios (OR and aOR, respectively) along with $95 \%$ confidence intervals (CI) to assess the association between each exposure variable of interest and acute leukemia subtypes. Covariates in the adjusted models were selected a priori based on previous literature for the specific acute leukemia subtype. For mothers who had children diagnosed with either ALL or AML, we considered the covariates of race/ethnicity (reference = non-Hispanic white), education level (reference $=$ completed high school), socioeconomic status (reference $=$ low-area level poverty), birth weight in grams (continuous), and child sex (reference $=$ male), along with the matching factor of birth year. Factors such as race/ethnicity [48], education [49], and SES [50] have been shown to be potential confounders in the context of ambient air pollution exposure. We additionally considered the covariate of birth weight, since high birth weight is associated with ALL [33,35,51]. Birth year was included as a covariate in all regression models since this was the matching factor for cases and controls. All statistical analyses were conducted using Stata, version 14.2 (StataCorp LP, College Station, TX, USA).

\section{Results}

Maternal and perinatal characteristics of acute leukemia cases born in Texas and diagnosed between 1995 and 2011 are shown in Table 1. Of the 2030 acute leukemia cases included in this study, the majority of cases were ALL (86.0\%), while the remaining $14.0 \%$ were AML. Regardless of acute leukemia subtype, most children were in the age group of $\geq 1$ to $\leq 5$ years $(67.8 \%)$, consistent with known childhood incidence rates [1]. In this study, almost all mothers lived in urban areas (95.8\%). Compared to controls, a higher proportion of cases were male $(54.9 \%$ of cases vs. $50.5 \%$ controls; $p$-value $=0.001)$, of large gestational size $(11.6 \%$ of cases vs. $8.4 \%$ controls; $p$-value $<0.001)$, and of Hispanic ethnicity $(53.5 \%$ of cases vs. $43.2 \%$ of controls; $p$-value $<0.001)$. Additionally, at the time of delivery, mothers with children diagnosed with acute leukemia were slightly more likely to be at least 35 years of age $(14.2 \%$ of case mothers vs. $10.7 \%$ of control mothers; $p$-value $<0.001)$ and not have a high school diploma ( $33.6 \%$ of case mothers vs. $29.8 \%$ of control mothers; $p$-value $=0.001$ ). Relative to controls, acute leukemia cases had similar proportions of birth terms $(p$-value $=0.891)$ and seasons of birth $(p$-value $=0.877)$. 
Table 1. Demographic characteristics of cases with acute leukemia and birth certificate controls in Texas, 1995-2011.

\begin{tabular}{|c|c|c|c|c|c|}
\hline Characteristics & $\begin{array}{l}\text { Any Leukemia } \\
\quad(n=2030)\end{array}$ & $\begin{array}{c}\text { ALL } \\
(n=1746)\end{array}$ & $\begin{array}{c}\text { AML } \\
(n=284)\end{array}$ & $\begin{array}{c}\text { Controls } \\
(n=20,300)\end{array}$ & $p$-Value \\
\hline \multicolumn{6}{|l|}{ Child } \\
\hline Child's sex, $n(\%)$ & & & & & 0.001 \\
\hline Male & 1114 (54.9) & $958(54.9)$ & $156(54.9)$ & $10,258(50.5)$ & \\
\hline Female & $916(45.1)$ & $788(45.1)$ & $128(45.1)$ & $10,042(49.5)$ & \\
\hline \multicolumn{6}{|l|}{ Age at diagnosis (years), $n(\%)$} \\
\hline$<1$ & $180(8.9)$ & $105(6.0)$ & $75(26.4)$ & & \\
\hline$\geq 1$ to $\leq 5$ & $1377(67.8)$ & $1232(70.6)$ & $145(51.1)$ & & \\
\hline$>5$ to $\leq 10$ & $368(18.1)$ & $329(18.8)$ & $39(13.7)$ & & \\
\hline$>10$ & $105(5.2)$ & $80(4.6)$ & $25(8.9)$ & & \\
\hline Season of birth, $n(\%)$ & & & & & 0.88 \\
\hline Summer (June-August) & $535(26.4)$ & $457(26.2)$ & $78(27.5)$ & $5361(26.4)$ & \\
\hline Fall (September-November) & $520(25.6)$ & $444(25.4)$ & $76(26.8)$ & $5228(25.8)$ & \\
\hline Winter (December-February) & $506(25.0)$ & $429(24.6)$ & $77(27.1)$ & $4908(24.2)$ & \\
\hline Spring (March-May) & $469(23.1)$ & $416(23.8)$ & $53(18.7)$ & $4803(23.7)$ & \\
\hline Term of birth, $n(\%)$ & & & & & 0.89 \\
\hline$<37$ weeks & $240(11.8)$ & $192(11.0)$ & $48(16.9)$ & $2351(11.6)$ & \\
\hline 37 to $<41$ weeks & $1553(76.5)$ & $1344(77.0)$ & $209(73.6)$ & $15,525(76.5)$ & \\
\hline 41 to $<42$ weeks & $156(7.7)$ & $140(8.0)$ & $16(5.6)$ & $1654(8.2)$ & \\
\hline 42 weeks to $<44$ weeks & $52(2.7)$ & $42(2.4)$ & $10(3.5)$ & $504(2.5)$ & \\
\hline Unknown & $29(1.4)$ & $28(1.6)$ & $1(0.35)$ & $266(1.3)$ & \\
\hline Gestational size, $n(\%)$ & & & & & $<0.001$ \\
\hline Small & $239(11.8)$ & $199(11.4)$ & $40(14.1)$ & $2778(13.7)$ & \\
\hline Appropriate & $1532(75.5)$ & $1316(75.4)$ & $216(76.1)$ & $15,601(76.9)$ & \\
\hline Large & $236(11.6)$ & $209(12.0)$ & $27(9.5)$ & $1700(8.4)$ & \\
\hline Unknown & $23(1.1)$ & $22(1.3)$ & $1(0.4)$ & $213(1.1)$ & \\
\hline \multicolumn{6}{|l|}{ Maternal } \\
\hline Maternal race/ethnicity, $n(\%)$ & & & & & $<0.001$ \\
\hline non-Hispanic white & $731(36.0)$ & $627(35.9)$ & $104(36.6)$ & $8118(40.0)$ & \\
\hline non-Hispanic black & $135(6.7)$ & $102(5.8)$ & $33(11.6)$ & $2595(12.8)$ & \\
\hline Hispanic & $1085(53.5)$ & $952(54.5)$ & $133(46.8)$ & $8772(43.2)$ & \\
\hline non-Hispanic other & $79(3.9)$ & $65(3.7)$ & $14(4.9)$ & $815(4.0)$ & \\
\hline Age at delivery (years), $n(\%)$ & & & & & $<0.001$ \\
\hline$<25$ & $766(37.7)$ & $663(38.0)$ & $103(36.3)$ & $8488(41.8)$ & \\
\hline $25-30$ & $568(28.0)$ & $487(27.9)$ & $81(28.5)$ & $5565(27.4)$ & \\
\hline $31-35$ & $408(20.1)$ & $361(20.7)$ & 47 (16.6) & $4083(20.1)$ & \\
\hline$\geq 35$ & $288(14.2)$ & $235(13.5)$ & $53(18.7)$ & $2164(10.7)$ & \\
\hline Education, $n(\%)$ & & & & & 0.001 \\
\hline$<$ High School & $682(33.6)$ & $586(33.6)$ & $96(33.8)$ & $6041(29.8)$ & \\
\hline Completed High School & $547(27.0)$ & 477 (27.3) & $70(24.7)$ & $5959(29.4)$ & \\
\hline$\geq$ High School & 778 (38.3) & $662(37.9)$ & $116(40.9)$ & $8100(39.9)$ & \\
\hline Unknown & $23(1.1)$ & $21(1.2)$ & $2(0.7)$ & $200(1.0)$ & \\
\hline \multicolumn{6}{|l|}{ Neighborhood at birth } \\
\hline Urban status, $n(\%)$ & & & & & 0.96 \\
\hline Urban & $1944(95.8)$ & $1676(96.0)$ & $268(94.4)$ & $19,435(95.7)$ & \\
\hline Rural & $86(4.2)$ & $70(4.0)$ & $16(5.6)$ & $865(4.3)$ & \\
\hline Area-Level poverty, $n(\%)$ & & & & & 0.06 \\
\hline$<15 \%$ of households & $1068(52.6)$ & $920(52.7)$ & $148(52.1)$ & $11,121(54.8)$ & \\
\hline$\geq 15 \%$ of households & $962(47.4)$ & $826(47.3)$ & $136(47.9)$ & $9179(45.2)$ & \\
\hline \multicolumn{6}{|l|}{ Maternal proximity to major roads } \\
\hline Continuous distance $(\mathrm{m})$, mean (SD) & $389.7(523.5)$ & $383.0(506.5)$ & $430.8(617.7)$ & $404.0(574.2)$ & 0.28 \\
\hline Within $500 \mathrm{~m}, n(\%)$ & & & & & 0.81 \\
\hline Exposed & $1551(76.4)$ & $1342(76.9)$ & $209(73.6)$ & $15,462(76.2)$ & \\
\hline Unexposed & $479(23.6)$ & $404(23.1)$ & $75(26.4)$ & $4838(23.8)$ & \\
\hline Roadway Density, $n(\%)^{\text {a }}$ & & & & & 0.74 \\
\hline Low & $479(23.6)$ & $404(23.1)$ & $75(26.4)$ & $4838(23.8)$ & \\
\hline Medium & $764(37.6)$ & $658(37.7)$ & $106(37.3)$ & 7767 (38.3) & \\
\hline High & $787(38.8)$ & $684(39.2)$ & $103(36.3)$ & 7695 (37.9) & \\
\hline
\end{tabular}

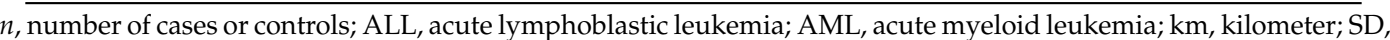
standard deviation; $\mathrm{m}$, meter. ${ }^{\mathrm{a}}$ Low, residence $>500 \mathrm{~m}$ from nearest major roadway; Medium, $>0$ and $<1.53 \mathrm{~km}$ of major roadways within $500 \mathrm{~m}$ residential radius; High, $\geq 1.53 \mathrm{~km}$ of major roadways within $500 \mathrm{~m}$ residential radius. 
For every one hundred meters closer that a mother resided to a major roadway at the time of delivery, the odds of having an offspring who developed ALL rose by $1 \%(\mathrm{aOR}=1.01 ; 95 \%$ CI: $1.00-1.02$; Table 2). This result was consistent among children $\geq 1$ to $\leq 5$ years of age ( $\mathrm{aOR}=1.01 ; 95 \% \mathrm{CI}: 1.00-1.02)$ and among children diagnosed at less than one year of age (aOR $=1.00 ; 95 \%$ CI: 0.971 .04 ; Supplemental Table S1). For every one hundred meters closer that a mother resided to a major roadway at the time of delivery, no increase or decrease in odds of developing AML was evident ( $\mathrm{aOR}=1.00 ; 95 \% \mathrm{CI}$ : 0.97 1.01). This estimate remained similar in subgroup analysis among children who developed AML between $\geq 1$ and $\leq 5$ years of age (aOR $=1.01 ; 95 \% \mathrm{CI}$ : 0.971 .04 ) and among those diagnosed at less than one year of age $(\mathrm{aOR}=0.98 ; 95 \%$ CI: 0.95 1.00; Supplemental Table S1).

Table 2. Associations between continuous distance of maternal residence to nearest major roadway and leukemia in offspring.

\begin{tabular}{|c|c|c|c|c|c|c|c|c|}
\hline \multirow[b]{2}{*}{$\begin{array}{l}\text { Leukemia } \\
\text { Subtype }\end{array}$} & \multirow[b]{2}{*}{$\begin{array}{c}\text { Cases } \\
\text { Mean (SD) }\end{array}$} & \multirow[b]{2}{*}{$\begin{array}{l}\text { Controls } \\
\text { Mean (SD) }\end{array}$} & \multicolumn{2}{|c|}{ All Ages } & \multicolumn{4}{|c|}{ Ages $\geq 1$ to $\leq 5$} \\
\hline & & & $\begin{array}{c}\text { OR }^{a} \\
(95 \% \text { CI })^{b}\end{array}$ & $\begin{array}{c}\text { aOR } \\
(95 \% \mathrm{CI})^{\mathrm{c}}\end{array}$ & $\begin{array}{c}\text { Cases } \\
\text { Mean (SD) }\end{array}$ & $\begin{array}{l}\text { Controls } \\
\text { Mean (SD) }\end{array}$ & $\begin{array}{c}\text { OR } \\
(95 \% \text { CI })^{b}\end{array}$ & $\begin{array}{c}\text { aOR } \\
(95 \% \text { CI })^{c}\end{array}$ \\
\hline ALL & $\begin{array}{c}383.0 \mathrm{~m} \\
(506.5)\end{array}$ & $\begin{array}{l}404.0 \mathrm{~m} \\
(574.2)\end{array}$ & $\begin{array}{c}1.01 \\
(1.00-1.02)\end{array}$ & $\begin{array}{c}1.01 \\
(1.00-1.02)\end{array}$ & $\begin{array}{c}398.4 \mathrm{~m} \\
(536.3)\end{array}$ & $\begin{array}{l}404.0 \mathrm{~m} \\
(574.2)\end{array}$ & $\begin{array}{c}1.00 \\
(1.00-1.01)\end{array}$ & $\begin{array}{c}1.01 \\
(1.00-1.02)\end{array}$ \\
\hline AML & $\begin{array}{c}430.8 \mathrm{~m} \\
(617.7)\end{array}$ & $\begin{array}{c}404.0 \mathrm{~m} \\
(574.2)\end{array}$ & $\begin{array}{c}1.00 \\
(0.98-1.01)\end{array}$ & $\begin{array}{c}1.00 \\
(0.97-1.01)\end{array}$ & $\begin{array}{c}386.6 \mathrm{~m} \\
(569.4)\end{array}$ & $\begin{array}{c}404.0 \mathrm{~m} \\
(574.2)\end{array}$ & $\begin{array}{c}1.01 \\
(0.98-1.04)\end{array}$ & $\begin{array}{c}1.01 \\
(0.97-1.04)\end{array}$ \\
\hline
\end{tabular}

ALL, acute lymphoblastic leukemia; AML, acute myeloid leukemia; SD, standard deviation; OR, odds ratio; CI, confidence interval; aOR, adjusted odds ratio. ${ }^{a}$ Table 2 ORs and aORs reflect estimates per $100 \mathrm{~m}$; ${ }^{\mathrm{b}}$ adjusted for birth year; ${ }^{c}$ adjusted for birth year, maternal race/ethnicity (categorical), maternal education (categorical), area-level poverty (categorical), birth weight in grams (continuous), and child sex (categorical).

Overall, a strong association between maternal residence within $500 \mathrm{~m}$ of a major roadway and acute leukemia risk was not evident (Table 3). For example, mothers living within $500 \mathrm{~m}$ of a major roadway at the time of delivery were only $3 \%$ more likely to have an offspring who developed ALL compared to those living further than $500 \mathrm{~m}(\mathrm{aOR}=1.03 ; 95 \% \mathrm{CI}: 0.91-1.16)$. In subgroup analysis among children $\geq 1$ to $\leq 5$ years of age, this association was slightly more apparent (aOR $=1.08 ; 95 \% \mathrm{CI}$ : 0.94-1.24), although with uncertainty, as the $95 \% \mathrm{CI}$ included the null. Among those diagnosed with ALL at less than one year of age, an inverse association was suggested (aOR: 0.79; 95\% CI: 0.51-1.24; Supplemental Table S1). There was also no strong association apparent between maternal residence within $500 \mathrm{~m}$ of a major roadway and AML risk.

Table 3. Associations between maternal residential proximity within $500 \mathrm{~m}$ of a major roadway and leukemia in offspring.

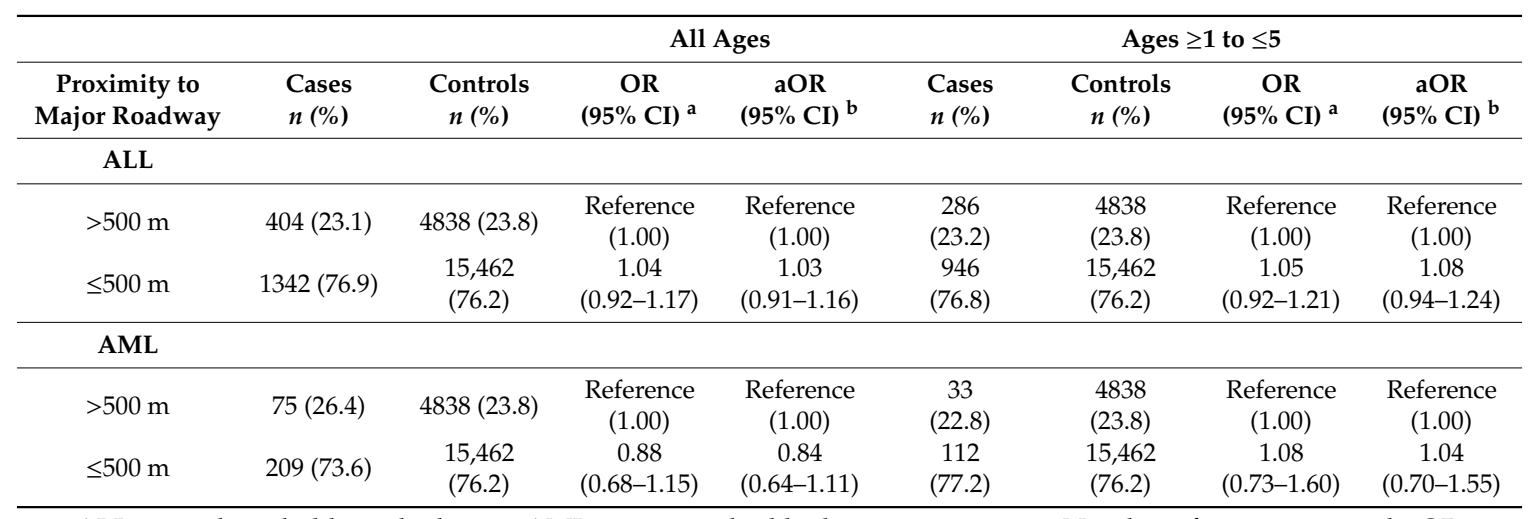

ALL, acute lymphoblastic leukemia; AML, acute myeloid leukemia; m, meter; $n$, Number of cases or controls; OR, odds ratio; $\mathrm{CI}$, confidence interval; aOR, adjusted odds ratio. ${ }^{a}$ adjusted for birth year; ${ }^{\mathrm{b}}$ adjusted for birth year, maternal race/ethnicity (categorical), maternal education (categorical), area-level poverty (categorical), birth weight in grams (continuous), and child sex (categorical). 
As with the other exposure metrics, roadway density was not strongly associated with the odds of having an offspring who would later develop ALL or AML (Table 4). Mothers residing in areas with medium roadway density ( $>0 \mathrm{~km}$ and $<2.11 \mathrm{~km}$ of major roadways within the $500 \mathrm{~m}$ residential radius) were as likely to have an offspring who developed ALL as mothers living in areas with low roadway density ( $\mathrm{aOR}=1.00 ; 95 \%$ CI: $0.88-1.14)$. Mothers residing in high roadway density areas $(\geq 2.11 \mathrm{~km}$ of major roadways within the $500 \mathrm{~m}$ residential radius) appeared to be $6 \%$ more likely to give birth to an offspring who developed ALL ( $\mathrm{aOR}=1.06$; $95 \%$ CI: 0.92-1.20), although with uncertainty, since the $95 \%$ confidence interval included the null. In terms of ALL risk among those cases diagnosed at $\geq 1$ to $\leq 5$ years of age born to mothers who lived in areas with medium road density, a slight increase in risk was suggested ( $\mathrm{aOR}=1.07 ; 95 \% \mathrm{CI}$ : $0.92-1.25$ ). This observation was slightly more apparent for mothers residing in areas of high roadway density who gave birth to an offspring who developed ALL between the ages of $\geq 1$ and $\leq 5$ ( $\mathrm{aOR}=1.09 ; 95 \%$ CI: $0.93-1.28)$. Among those diagnosed at less than one year of age, modest inverse associations were suggested for both medium and high roadway densities in relation to ALL (Supplemental Table S1).

Table 4. Associations between maternal residential roadway density and leukemia in offspring.

\begin{tabular}{|c|c|c|c|c|c|c|c|c|}
\hline \multirow[b]{2}{*}{$\begin{array}{l}\text { Roadway } \\
\text { Density }\end{array}$} & \multirow[b]{2}{*}{$\begin{array}{l}\text { Cases } \\
n(\%)\end{array}$} & \multirow[b]{2}{*}{$\begin{array}{c}\text { Controls } n \\
(\%)\end{array}$} & \multicolumn{2}{|c|}{ All Ages } & \multicolumn{4}{|c|}{ Ages $\geq 1$ to $\leq 5$} \\
\hline & & & $\begin{array}{c}\text { OR } \\
(95 \% \mathrm{CI})^{\mathrm{a}}\end{array}$ & $\begin{array}{c}\mathrm{aOR} \\
(95 \% \mathrm{CI})^{\mathrm{b}}\end{array}$ & $\begin{array}{c}\text { Cases } n \\
(\%)\end{array}$ & $\begin{array}{c}\text { Controls } \\
n(\%)\end{array}$ & $\begin{array}{c}\text { OR } \\
(95 \% \mathrm{CI})^{a}\end{array}$ & $\begin{array}{c}\mathrm{aOR} \\
(95 \% \mathrm{CI})^{b}\end{array}$ \\
\hline \multicolumn{9}{|l|}{ ALL } \\
\hline Low & $404(23.1)$ & $4838(23.8)$ & $\begin{array}{c}\text { Reference } \\
(1.00)\end{array}$ & $\begin{array}{c}\text { Reference } \\
(1.00)\end{array}$ & $286(23.2)$ & 4838 (23.8) & $\begin{array}{c}\text { Reference } \\
(1.00)\end{array}$ & $\begin{array}{c}\text { Reference } \\
(1.00)\end{array}$ \\
\hline Medium & $658(37.7)$ & 7767 (38.3) & $\begin{array}{c}1.01 \\
(0.89-1.15)\end{array}$ & $\begin{array}{c}1.00 \\
(0.88-1.14)\end{array}$ & $476(38.6)$ & 7767 (38.3) & $\begin{array}{c}1.05 \\
(0.90-1.22)\end{array}$ & $\begin{array}{c}1.07 \\
(0.92-1.25)\end{array}$ \\
\hline High & $684(39.2)$ & 7695 (37.9) & $\begin{array}{c}1.06 \\
(0.93-1.21)\end{array}$ & $\begin{array}{c}1.06 \\
(0.92-1.20)\end{array}$ & $470(38.2)$ & 7695 (37.9) & $\begin{array}{c}1.06 \\
(0.91-1.23)\end{array}$ & $\begin{array}{c}1.09 \\
(0.93-1.28)\end{array}$ \\
\hline \multicolumn{9}{|l|}{ AML } \\
\hline Low & $75(26.4)$ & $4838(23.8)$ & $\begin{array}{c}\text { Reference } \\
(1.00)\end{array}$ & $\begin{array}{c}\text { Reference } \\
(1.00)\end{array}$ & $33(22.8)$ & $4838(23.8)$ & $\begin{array}{c}\text { Reference } \\
(1.00)\end{array}$ & $\begin{array}{c}\text { Reference } \\
(1.00)\end{array}$ \\
\hline Medium & $106(37.3)$ & 7767 (38.3) & $\begin{array}{c}0.89 \\
(0.66-1.20)\end{array}$ & $\begin{array}{c}0.86 \\
(0.64-1.16)\end{array}$ & $59(40.7)$ & 7767 (38.3) & $\begin{array}{c}1.13 \\
(0.74-1.74)\end{array}$ & $\begin{array}{c}1.08 \\
(0.70-1.67)\end{array}$ \\
\hline High & $103(36.3)$ & 7695 (37.9) & $\begin{array}{c}0.87 \\
(0.65-1.18)\end{array}$ & $\begin{array}{c}0.83 \\
(0.61-1.13)\end{array}$ & $53(36.6)$ & 7695 (37.9) & $\begin{array}{c}1.03 \\
(0.67-1.60)\end{array}$ & $\begin{array}{c}0.99 \\
(0.64-1.55)\end{array}$ \\
\hline
\end{tabular}

ALL, acute lymphoblastic leukemia; AML, acute myeloid leukemia; $n$, number of cases or controls; OR, odds ratio; $\mathrm{CI}$, confidence interval; aOR, adjusted odds ratio. ${ }^{a}$ Adjusted for birth year; ${ }^{\mathrm{b}}$ adjusted for birth year, maternal race/ethnicity (categorical), maternal education (categorical), area-level poverty (categorical), and birth weight in grams (continuous) and child sex (categorical).

A strong effect was not evident between maternal residence in medium or high roadway density areas at the time of birth and AML $(\mathrm{aOR}=0.86 ; 95 \% \mathrm{CI}$ : $0.64-1.16$, and $\mathrm{aOR}=0.83 ; 95 \% \mathrm{CI}$ : $0.61-1.13$, respectively) among all ages. Among cases diagnosed between $\geq 1$ and $\leq 5$ years of age, no association was evident between maternal residence in medium roadway density areas and AML, although the effect estimate trended toward a positive association (aOR $=1.08 ; 95 \%$ CI: $0.70-1.67)$. Further, these younger AML cases were as likely to have a mother who resided in areas of high roadway density at time of birth as a mother who resided in low roadway density areas (aOR $=0.99 ; 95 \% \mathrm{CI}$ : $0.64-1.55$ ). Among those diagnosed at less than one year of age, modest inverse associations were suggested for both medium and high roadway densities in relation to AML (Supplemental Table S1).

\section{Discussion}

In this population-based case-control study, across all three proximity measures, modest effects at best were evident for both ALL and AML. In general, the association between major roadways and ALL risk was slightly stronger in children ages $\geq 1$ to $\leq 5$ years. However, effect estimates remained relatively close to the null suggesting that proximity to major roadways, as a proxy for measuring 
ambient air pollution, is not strongly associated with acute leukemia development. Among those diagnosed at less than one year of age, there was no association between distance to a major roadway and infant ALL or AML (ALL aOR = 1.00; 95\% CI: 0.97-1.04 and AML aOR: 0.98; 95\% CI: 0.95-1.00). When evaluating proximity and roadway density, inverse associations among those diagnosed under one year of age were suggested. Past studies have suggested that exposure to traffic-related air pollution may increase the risk of developing childhood malignancies such as acute leukemia [24-27]. Overall, research is inconclusive, and our results are consistent with several previous studies suggesting that traffic-related pollution may not strongly affect the odds of childhood cancer [13,52-55]. According to one of these studies, Janitz et al., found a modest, positive association between childhood acute leukemia and exposure to the fourth quartile of nitrogen dioxide $\left(\mathrm{NO}_{2} ; 11.19-19.89 \mathrm{ppb} ; \mathrm{aOR}=1.08\right.$; 95\% CI: 0.75-1.55) [54]. In the current study, when the mother resided within $500 \mathrm{~m}$ of a major roadway at the time of birth, there was no observed trend between living in high roadway density areas and the development of acute leukemia $(\mathrm{aOR}=1.02 ; 95 \% \mathrm{CI}$ : 0.90-1.15) compared to mothers living in low roadway density areas. Similarly, Houot et al., found that when children lived $<150 \mathrm{~m}$ of a major roadway at the time of diagnosis, there was no strong increase in risk of ALL or AML (OR $=1.0 ; 95 \%$ CI: $0.9-1.1$, and OR $=1.2 ; 95 \%$ CI: $0.9-1.5$, respectively) [55]. In a study conducted by Raaschou-Nielsen et al., no elevated risk for a child developing acute leukemia was evident if the mother resided in traffic areas with an average of $\geq 10,000$ vehicles per day during pregnancy $(\mathrm{OR}=0.8$; 95\% CI: $0.5-1.3$ ) compared to children whose mothers resided in traffic areas with an average of $<500$ vehicles per day [52].

The current study utilized maternal residence at the time of birth as a proxy measure to evaluate exposure to air pollution. It is established that traffic-related pollution contains harmful particulate matter and identified human carcinogens. For instance, exposure to particulate air pollution is known to contain free radicals and cause oxidative stress which facilitates DNA damage and can trigger mutagenesis [56,57]. Furthermore, maternal exposure to high levels of polycyclic aromatic hydrocarbons (PAHs), carcinogenic compounds found in motor vehicle exhaust, is linked to fetal PAH-DNA adduct formation and can increase the risk of the offspring developing cancer later in life $[58,59]$. Moreover, aromatic hydrocarbons like benzene have been classified by the International Agency for Research on Cancer (IARC) as carcinogenic to humans, giving rise to AML and possibly the risk of ALL [11,60]. Due to these negative health implications of traffic-related air pollution, we sought to determine if exposure to traffic-related pollution affects the odds of developing childhood acute leukemia.

These results should be considered in light of certain limitations. For example, this study relied on maternal proximity to major roadways as a substitute measure for determining air pollution exposure. This type of measurement was applied as it is more difficult and costly to use other methods to obtain personal exposure levels to air pollutants. Moreover, air monitors are placed inconsistently across Texas and may not necessarily yield accurate results when compared to the use of proximity measures, which have been shown to be an adequate proxy for estimating air pollution including particulate matter (e.g., $\mathrm{NO}_{2}$ ) [61]. Another limitation is that residential mobility could lead to exposure misclassification. However, recent studies suggest that individuals tend to move short distances into areas with similar air pollution profiles [62-64]. Over $95 \%$ of both case and control mothers in this study resided in urban areas at time of delivery. Therefore, our results may reflect urban exposure levels. While there is variability in air pollution levels across urban areas, our model may not have adequately captured that. However, as this is a population-based study, we obtained cases and controls from across the entire state of Texas, which should help to lessen any potential bias related to this. Another limitation is that as the analyzed data were based on birth records, our investigations were constrained to within this data source. Specifically, we were unable to investigate how observed associations would be modulated if other strong risk predictors of acute leukemia and markers of childhood leukemia heterogeneity, such as cytogenetic abnormalities [65,66], were taken into account. We were also unable to assess the impact of other maternal health behaviors that might influence risk, 
or how other potentially confounding factors (e.g., environmental risk factors) may have influenced the reported results. It is important to note that while these limitations relate to our use of vital statistics, birth statistics in combination with cancer registry data have been leveraged to inform how maternal and perinatal characteristics impact the risk of several childhood cancers [67-70]. Another limitation is that we received the geocoding data for this study from the State Health Services in Texas. Due to data suppression rules, data could only be evaluated for buffers of within 500 meters to a residence to limit the potential for subject identification. Therefore, we were unable to assess shorter exposure distances in this study. However, there is support for analyses investigating $500 \mathrm{~m}$ buffers as done herein $[19,31,71]$. Future studies should put planning in place to consider smaller buffer regions.

This study has several important strengths. One is the use of a population-based design that reduced the potential effects of participation bias. The use of birth records to identify cases and controls helped to ensure that the population of interest was well represented [72]. Information from birth certificates has also been shown to be a reliable source of data $[73,74]$. Moreover, this study contains 16 years of cancer incidence data drawn from one of the largest statewide cancer registries, in a state characterized by variable and high levels of traffic-related air pollution and roadway densities. Coupled with the large sample size of over 2000 acute leukemia cases, which to our knowledge is one of the largest studies conducted in Texas on the relationship between maternal proximity to major roadways and childhood leukemia risk, this study was adequately powered to assess the impact of traffic-related air pollution on the odds of developing childhood acute leukemia. A further strength of these analyses is that several measures of maternal proximity to major roadways were assessed (continuous distance to the nearest roadway, if the mother resided within $500 \mathrm{~m}$ of a major roadway, and roadway density), and results across all three measures remained relatively consistent. This analysis also focused on childhood acute leukemia, which tends to have shorter latency periods and fewer methodological obstacles for this type of study [75]. The ability to focus on children allowed for suitable exposure measurement as measurement at the time of delivery is generally considered relevant for other early life exposures, such as at the time of conception [64] and early childhood [76].

\section{Conclusions}

This large population-based assessment suggests that a modest effect exists between mothers residing close $(<500 \mathrm{~m})$ to a major roadway or in high roadway density areas and the odds of giving birth to a child who will develop ALL or AML. These results will inform future research studying this relationship as increasing segments of the U.S. population live in or near major metropolitan areas with dense networks of major roadways. Upcoming studies should utilize novel methods to directly measure exposure, such as through biomarkers of traffic-related air pollution exposure, and evaluate the role of other potential genetic and environmental factors in the development of acute leukemia.

Supplementary Materials: The following are available online at http://www.mdpi.com/1660-4601/16/11/2029/s1, Table S1: Associations between Proximity of Maternal Residence to Nearest Major Roadway and Leukemia in Offspring Diagnosed Under One Year of Age.

Author Contributions: Conceptualization, H.E.D. and P.J.L.; methodology, E.C.P.-G., H.E.D., M.E.S., and P.J.L.; formal analysis, E.C.P.-G. and M.T.; data curation, H.E.D., P.J.L., E.C.P.-G., and M.T.; writing-original draft preparation, E.C.P.-G., M.T., and P.J.L.; writing-review and editing, K.R.R., M.E.S., H.E.D., P.J.L., E.C.P.-G., and M.T.; supervision, M.E.S. and P.J.L.

Funding: This research was funded by the Summer Medical and Research Training Program at Baylor College of Medicine, 2535338502 [awarded to M.T.]; Cancer Prevention \& Research Institute of Texas Award, RP140258 [awarded to P.J.L.]; Alex's Lemonade Stand Foundation Epidemiology Grant [awarded to P.J.L.]; and the American Society of Hematology Scholar Award in Clinical Research [awarded to E.C.P.-G.]. The funding sponsors had no involvement in any portion of the study design, data collection, analysis, interpretation of data, writing of the report, or decision to publish this study.

Acknowledgments: Cancer data have been provided by the Texas Cancer Registry, Cancer Epidemiology and Surveillance Branch, Texas Department of State Health Services, 1100 West 49th Street, Austin, TX 78756, http://www.dshs.state.tx.us/tcr/default.shtm, or (512) 776-3080. Roadway data were obtained from the Texas National Resources Information System. The authors thank the children and their parents for their participation. 
Conflicts of Interest: The authors declare no conflict of interest.

\section{References}

1. United States Department of Health and Human Services Centers for Disease Control and Prevention: 1999-2014 Incidence and Mortality Data. United States Cancer Statistics, National Cancer Institute. WONDER Online Database. Available online: https://wonder.cdc.gov/ (accessed on 26 March 2018).

2. Ma, H.; Sun, H.; Sun, X. Survival improvement by decade of patients aged 0-14 years with acute lymphoblastic leukemia: A SEER analysis. Sci. Rep. 2014, 4, 4227. [CrossRef] [PubMed]

3. Pulte, D.; Gondos, A.; Brenner, H. Expected long-term survival of patients diagnosed with acute myeloblastic leukemia during 2006-2010. Ann. Oncol. 2010, 21, 335-341. [CrossRef] [PubMed]

4. American Cancer Society. Cancer Facts \& Figures 2018; American Cancer Society: Atlanta, GA, USA, 2018; Available online: https://www.cancer.org/research/cancer-facts-statistics/all-cancer-facts-figures/cancer-factsfigures-2018.html (accessed on 24 March 2018).

5. Haddy, T.B.; Mosher, R.B.; Reaman, G.H. Late effects in long-term survivors after treatment for childhood acute leukemia. Clin. Pediatr. 2009, 48, 601-608. [CrossRef] [PubMed]

6. Wallace, W.H.; Thompson, L.; Anderson, R.A. Guideline Development, G. Long term follow-up of survivors of childhood cancer: Summary of updated SIGN guidance. BMJ 2013, 346, f1190. [CrossRef] [PubMed]

7. Barrington-Trimis, J.L.; Cockburn, M.; Metayer, C.; Gauderman, W.J.; Wiemels, J.; McKean-Cowdin, R. Trends in childhood leukemia incidence over two decades from 1992 to 2013. Int. J. Cancer 2017, 140, 1000-1008. [CrossRef]

8. Xie, Y.; Davies, S.M.; Xiang, Y.; Robison, L.L.; Ross, J.A. Trends in leukemia incidence and survival in the United States (1973-1998). Cancer 2003, 97, 2229-2235. [CrossRef] [PubMed]

9. Wiemels, J. Perspectives on the causes of childhood leukemia. Chem. Biol. Interact. 2012, 196, 59-67. [CrossRef]

10. Ghosh, J.K.; Heck, J.E.; Cockburn, M.; Su, J.; Jerrett, M.; Ritz, B. Prenatal exposure to traffic-related air pollution and risk of early childhood cancers. Am. J. Epidemiol. 2013, 178, 1233-1239. [CrossRef]

11. International Agency for Research on Cancer: Monographs on the Evaluation of Carcinogenic Risks to Humans. 2016, Volume 109, pp. 1-149. Available online: http://monographs.iarc.fr/ENG/Monographs/ vol109/index.php (accessed on 25 March 2018).

12. Chen, H.; Goldberg, M.S. The effects of outdoor air pollution on chronic illnesses. McGill J. Med. 2009, 12, 58-64.

13. Health Effects Institute: Traffic-related air pollution: A critical review of the literature on emissions, exposure, and health effects. HEI Spec. Rep. 2010, 17, 1-386.

14. Rundell, K.W.; Caviston, R.; Hollenbach, A.M.; Murphy, K. Vehicular air pollution, playgrounds, and youth athletic fields. Inhal. Toxicol. 2006, 18, 541-547. [CrossRef] [PubMed]

15. Zhu, Y.; Kuhn, T.; Mayo, P.; Hinds, W.C. Comparison of daytime and nighttime concentration profiles and size distributions of ultrafine particles near a major highway. Environ. Sci. Technol. 2006, 40, 2531-2536. [CrossRef] [PubMed]

16. Langholz, B.; Ebi, K.L.; Thomas, D.C.; Peters, J.M.; London, S.J. Traffic Density and the Risk of Childhood Leukemia in a Los Angeles Case-Control Study. Ann. Epidemiol. 2002, 12, 482-487. [CrossRef]

17. Reynolds, P.; Von Behren, J.; Gunier, R.B.; Goldberg, D.E.; Hertz, A. Residential exposure to traffic in California and childhood cancer. Epidemiology 2004, 15, 6-12. [CrossRef] [PubMed]

18. Carlos-Wallace, F.M.; Zhang, L.; Smith, M.T.; Rader, G.; Steinmaus, C. Parental, In Utero, and Early-Life Exposure to Benzene and the Risk of Childhood Leukemia: A Meta-Analysis. Am. J. Epidemiol. 2016, 183, 1-14. [CrossRef] [PubMed]

19. Danysh, H.E.; Zhang, K.; Mitchell, L.E.; Scheurer, M.E.; Lupo, P.J. Maternal residential proximity to major roadways at delivery and childhood central nervous system tumors. Environ. Res. 2016, 146, 315-322. [CrossRef] [PubMed]

20. Savitz, D.A.; Feingold, L. Association of childhood cancer with residential traffic density. Scand. J. Work Environ. Health 1989, 360-363. [CrossRef] 
21. Tamayo-Uria, I.; Boldo, E.; García-Pérez, J.; Gómez-Barroso, D.; Romaguera, E.P.; Cirach, M.; Ramis, R. Childhood leukaemia risk and residential proximity to busy roads. Environ. Int. 2018, 121, 332-339. [CrossRef]

22. Boothe, V.L.; Boehmer, T.K.; Wendel, A.M.; Yip, F.Y. Residential traffic exposure and childhood leukemia: A systematic review and meta-analysis. Am. J. Prev. Med. 2014, 46, 413-422. [CrossRef]

23. Kim, J.J.; Smorodinsky, S.; Lipsett, M.; Singer, B.C.; Hodgson, A.T.; Ostro, B. Traffic-related air pollution near busy roads: The East Bay Children's Respiratory Health Study. Am. J. Respir. Crit. Care Med. 2004, 170, 520-526. [CrossRef]

24. Knox, E.G. Roads, railways, and childhood cancers. J. Epidemiol. Community Health 2006, 60, $136-141$. [CrossRef] [PubMed]

25. Heck, J.E.; Wu, J.; Lombardi, C.; Qiu, J.; Meyers, T.J.; Wilhelm, M.; Cockburn, M.; Ritz, B. Childhood cancer and traffic-related air pollution exposure in pregnancy and early life. Environ. Health Perspect. 2013, 121, 1385-1391. [CrossRef] [PubMed]

26. Filippini, T.; Heck, J.E.; Malagoli, C.; Del Giovane, C.; Vinceti, M. A review and meta-analysis of outdoor air pollution and risk of childhood leukemia. J. Environ. Sci. Health C Environ. Carcinog. Ecotoxicol. Rev. 2015, 33, 36-66. [CrossRef] [PubMed]

27. Spycher, B.D.; Feller, M.; Roosli, M.; Ammann, R.A.; Diezi, M.; Egger, M.; Kuehni, C.E. Childhood cancer and residential exposure to highways: A nationwide cohort study. Eur. J. Epidemiol. 2015, 30, 1263-1275. [CrossRef] [PubMed]

28. Steliarova-Foucher, E.; Stiller, C.; Lacour, B.; Kaatsch, P. International Classification of Childhood Cancer, third edition. Cancer 2005, 103, 1457-1467. [CrossRef] [PubMed]

29. Texas National Resources Information System 2014. Maps \& Data: Transportation StratMap. Texas Natural Resources Information System. Available online: https:/tnris.org/data-catalog/entry/stratmaptransportation/ (accessed on 30 April 2018).

30. U.S. Census Bureau. TIGER/Line Files: Technical Documentation; U.S. Census Bureau: Washington, DC, USA, 2007; pp. 88-91. Available online: https://www.census.gov/geo/maps-data/data/tiger-line.html (accessed on 2 April 2018).

31. Kumar, S.V.; Lupo, P.J.; Pompeii, L.A.; Danysh, H.E. Maternal Residential Proximity to Major Roadways and Pediatric Embryonal Tumors in Offspring. Int. J. Environ. Res. Public Health 2018, 15, 505. [CrossRef] [PubMed]

32. Matz, C.J.; Stieb, D.M.; Davis, K.; Egyed, M.; Rose, A.; Chou, B.; Brion, O. Effects of age, season, gender and urban-rural status on time-activity: CanadianHuman Activity Pattern Survey 2 (CHAPS 2). Int. J. Environ. Res. Public Health 2014, 11, 2108-2124. [CrossRef]

33. Oksuzyan, S.; Crespi, C.M.; Cockburn, M.; Mezei, G.; Kheifets, L. Birth weight and other perinatal characteristics and childhood leukemia in California. Cancer Epidemiol. 2012, 36, e359-e365. [CrossRef]

34. Maule, M.M.; Merletti, F.; Pastore, G.; Magnani, C.; Richiardi, L. Effects of maternal age and cohort of birth on incidence time trends of childhood acute lymphoblastic leukemia. Cancer Epidemiol. Biomark. Prev. 2007, 16, 347-351. [CrossRef]

35. Hjalgrim, L.L.; Westergaard, T.; Rostgaard, K.; Schmiegelow, K.; Melbye, M.; Hjalgrim, H.; Engels, E.A. Birth weight as a risk factor for childhood leukemia: A meta-analysis of 18 epidemiologic studies. Am. J. Epidemiol. 2003, 158, 724-735. [CrossRef]

36. Huang, Q.T.; Gao, Y.F.; Zhong, M.; Yu, Y.H. Preterm Birth and Subsequent Risk of Acute Childhood Leukemia: A Meta-Analysis of Observational Studies. Cell. Physiol. Biochem. 2016, 39, 1229-1238. [CrossRef]

37. Oksuzyan, S.; Crespi, C.M.; Cockburn, M.; Mezei, G.; Vergara, X.; Kheifets, L. Race/ethnicity and the risk of childhood leukaemia: A case-control study in California. J. Epidemiol. Community Health 2015, 69, 795-802. [CrossRef] [PubMed]

38. Raaschou-Nielsen, O.; Obel, J.; Dalton, S.; TjOnneland, A.; Hansen, J. Socioeconomic status and risk of childhood leukaemia in Denmark. Scand. J. Public Health 2004, 32, 279-286. [CrossRef] [PubMed]

39. Adelman, A.S.; McLaughlin, C.C.; Wu, X.C.; Chen, V.W.; Groves, F.D. Urbanisation and incidence of acute lymphocytic leukaemia among United States children aged 0-4. Br. J. Cancer 2005, 92, 2084-2088. [CrossRef] [PubMed]

40. Wier, M.L.; Pearl, M.; Kharrazi, M. Gestational age estimation on United States livebirth certificates: A historical overview. Paediatr. Perinat. Epidemiol. 2007, 21, 4-12. [CrossRef] [PubMed] 
41. Peckham-Gregory, E.C.; McClain, K.L.; Allen, C.E.; Scheurer, M.E.; Lupo, P.J. The role of parental and perinatal characteristics on Langerhans cell histiocytosis: Characterizing increased risk among Hispanics. Ann. Epidemiol. 2018, 28, 521-528. [CrossRef] [PubMed]

42. Lynch, C.D.; Zhang, J. The research implications of the selection of a gestational age estimation method. Paediatr. Perinat. Epidemiol. 2007, 21 (Suppl. 2), 86-96. [CrossRef]

43. Dietz, P.M.; England, L.J.; Callaghan, W.M.; Pearl, M.; Wier, M.L.; Kharrazi, M. A comparison of LMP-based and ultrasound-based estimates of gestational age using linked California livebirth and prenatal screening records. Paediatr. Perinat. Epidemiol. 2007, 21, 62-71. [CrossRef] [PubMed]

44. Talge, N.M.; Mudd, L.M.; Sikorskii, A.; Basso, O. United States birth weight reference corrected for implausible gestational age estimates. Pediatrics 2014, 133, 844-853. [CrossRef] [PubMed]

45. U.S. Census Bureau. 2010 Geographic Terms and Concepts-Census Tract. 2012. Available online: https://www.census.gov/geo/reference/gtc/gtc_ct.html (accessed on 18 January 2018).

46. Harrison, C.J. Cytogenetics of paediatric and adolescent acute lymphoblastic leukaemia. Br. J. Haematol. 2009, 144, 147-156. [CrossRef] [PubMed]

47. Creutzig, U.; Zimmermann, M.; Reinhardt, D.; Rasche, M.; von Neuhoff, C.; Alpermann, T.; Dworzak, M.; Perglerova, K.; Zemanova, Z.; Tchinda, J.; et al. Changes in cytogenetics and molecular genetics in acute myeloid leukemia from childhood to adult age groups. Cancer 2016, 122, 3821-3830. [CrossRef] [PubMed]

48. Linder, S.H.; Marko, D.; Sexton, K. Cumulative Cancer Risk from Air Pollution in Houston: Disparities in Risk Burden and Social Disadvantage. Environ. Sci. Technol. 2008, 42, 4312-4322. [CrossRef] [PubMed]

49. Gray, S.C.; Edwards, S.E.; Schultz, B.D.; Miranda, M.L. Assessing the impact of race, social factors and air pollution on birth outcomes: A population-based study. Environ. Health 2014, 13, 4. [CrossRef] [PubMed]

50. Houston, D.; Wu, J.; Ong, P.; Winer, A. Structural Disparities of Urban Traffic in Southern California: Implications for Vehicle-Related Air Pollution Exposure in Minority and High-Poverty Neighborhoods. J. Urban Aff. 2016, 26, 565-592. [CrossRef]

51. Milne, E.; Laurvick, C.L.; Blair, E.; Bower, C.; de Klerk, N. Fetal growth and acute childhood leukemia: Looking beyond birth weight. Am. J. Epidemiol. 2007, 166, 151-159. [CrossRef] [PubMed]

52. Raaschou-Nielsen, O.; Hertel, O.; Thomsen, B.L.; Olsen, J.H. Air Pollution from Traffic at the Residence of Children with Cancer. Am. J. Epidemiol. 2001, 153, 433-443. [CrossRef] [PubMed]

53. Reynolds, P.; Elkin, E.; Scalf, R.; Von Behren, J.; Neutra, R.R. A case-control pilot study of traffic exposures and early childhood leukemia using a geographic information system. Bioelectromagnetics 2001, 22 (Suppl. 5), S58-S68. [CrossRef]

54. Janitz, A.E.; Campbell, J.E.; Magzamen, S.; Pate, A.; Stoner, J.A.; Peck, J.D. Traffic-related air pollution and childhood acute leukemia in Oklahoma. Environ. Res. 2016, 148, 102-111. [CrossRef]

55. Houot, J.; Marquant, F.; Goujon, S.; Faure, L.; Honore, C.; Roth, M.H.; Hemon, D.; Clavel, J. Residential Proximity to Heavy-Traffic Roads, Benzene Exposure, and Childhood Leukemia-The GEOCAP Study, 2002-2007. Am. J. Epidemiol. 2015, 182, 685-693. [CrossRef]

56. Risom, L.; Moller, P.; Loft, S. Oxidative stress-induced DNA damage by particulate air pollution. Mutat. Res. 2005, 592, 119-137. [CrossRef]

57. Moller, P.; Jacobsen, N.R.; Folkmann, J.K.; Danielsen, P.H.; Mikkelsen, L.; Hemmingsen, J.G.; Vesterdal, L.K.; Forchhammer, L.; Wallin, H.; Loft, S. Role of oxidative damage in toxicity of particulates. Free Radic. Res. 2010, 44, 1-46. [CrossRef] [PubMed]

58. Herbstman, J.B.; Tang, D.; Zhu, D.; Qu, L.; Sjodin, A.; Li, Z.; Camann, D.; Perera, F.P. Prenatal exposure to polycyclic aromatic hydrocarbons, benzo[a]pyrene-DNA adducts, and genomic DNA methylation in cord blood. Environ. Health Perspect. 2012, 120, 733-738. [CrossRef] [PubMed]

59. Perera, F.; Tang, D.; Whyatt, R.; Lederman, S.A.; Jedrychowski, W. DNA damage from polycyclic aromatic hydrocarbons measured by benzo[a]pyrene-DNA adducts in mothers and newborns from Northern Manhattan, the World Trade Center Area, Poland, and China. Cancer Epidemiol. Biomark. Prev. 2005, 14, 709-714. [CrossRef] [PubMed]

60. Stenehjem, J.S.; Kjærheim, K.; Bråtveit, M.; Samuelsen, S.O.; Barone-Adesi, F.; Rothman, N.; Lan, Q.; Grimsrud, T.K. Benzene exposure and risk of lymphohaematopoietic cancers in 25,000 offshore oil industry workers. Br. J. Cancer 2015, 112, 1603. [CrossRef] [PubMed] 
61. Van Roosbroeck, S.; Wichmann, J.; Janssen, N.A.; Hoek, G.; van Wijnen, J.H.; Lebret, E.; Brunekreef, B. Long-term personal exposure to traffic-related air pollution among school children, a validation study. Sci. Total Environ. 2006, 368, 565-573. [CrossRef] [PubMed]

62. Chen, L.; Bell, E.M.; Caton, A.R.; Druschel, C.M.; Lin, S. Residential mobility during pregnancy and the potential for ambient air pollution exposure misclassification. Environ. Res. 2010, 110, 162-168. [CrossRef]

63. Bell, M.L.; Belanger, K. Review of research on residential mobility during pregnancy: Consequences for assessment of prenatal environmental exposures. J. Expo. Sci. Environ. Epidemiol. 2012, 22, 429-438. [CrossRef]

64. Lupo, P.J.; Symanski, E.; Chan, W.; Mitchell, L.E.; Waller, D.K.; Canfield, M.A.; Langlois, P.H. Differences in exposure assignment between conception and delivery: The impact of maternal mobility. Paediatr. Perinat. Epidemiol. 2010, 24, 200-208. [CrossRef]

65. Greaves, M.F.; Wiemels, J. Origins of chromosome translocations in childhood leukaemia. Nat. Rev. Cancer 2003, 3, 639-649. [CrossRef]

66. Forestier, E.; Schmiegelow, K.; Nordic Society of Paediatric, H.; Oncology, N. The incidence peaks of the childhood acute leukemias reflect specific cytogenetic aberrations. J. Pediatr. Hematol. Oncol. 2006, 28, 486-495. [CrossRef]

67. Puumala, S.E.; Carozza, S.E.; Chow, E.J.; Fox, E.E.; Horel, S.; Johnson, K.J.; McLaughlin, C.; Mueller, B.A.; Reynolds, P.; Von Behren, J.; et al. Childhood Cancer among Twins and Higher Order Multiples. Cancer Epidemiol. Biomark. Prev. 2009, 18, 162-168. [CrossRef] [PubMed]

68. O’Neill, K.A.; Murphy, M.F.; Bunch, K.J.; Puumala, S.E.; Carozza, S.E.; Chow, E.J.; Mueller, B.A.; McLaughlin, C.C.; Reynolds, P.; Vincent, T.J.; et al. Infant birthweight and risk of childhood cancer: International population-based case control studies of 40,000 cases. Int. J. Epidemiol. 2015, 44, 153-168. [CrossRef] [PubMed]

69. Johnson, K.J.; Carozza, S.E.; Chow, E.J.; Fox, E.E.; Horel, S.; McLaughlin, C.C.; Mueller, B.A.; Puumala, S.E.; Reynolds, P.; Von Behren, J.; et al. Parental age and risk of childhood cancer: A pooled analysis. Epidemiology 2009, 20, 475-483. [CrossRef] [PubMed]

70. Spector, L.G.; Puumala, S.E.; Carozza, S.E.; Chow, E.J.; Fox, E.E.; Horel, S.; Johnson, K.J.; McLaughlin, C.C.; Reynolds, P.; Von Behren, J.; et al. Cancer risk among children with very low birth weight. Pediatrics 2009, 124, 96-104. [CrossRef] [PubMed]

71. Danysh, H.E.; Mitchell, L.E.; Zhang, K.; Scheurer, M.E.; Lupo, P.J. Traffic-related air pollution and the incidence of childhood central nervous system tumors: Texas, 2001-2009. Pediatr. Blood Cancer 2015, 62, 1572-1578. [CrossRef] [PubMed]

72. Ma, X.; Buffler, P.A.; Layefsky, M.; Does, M.B.; Reynolds, P. Control selection strategies in case-control studies of childhood diseases. Am. J. Epidemiol. 2004, 159, 915-921. [CrossRef]

73. Honein, M.A.; Paulozzi, L.J.; Watkins, M.L. Maternal smoking and birth defects: Validity of birth certificate data for effect estimation. Public Health Rep. 2001, 116, 327-335. [CrossRef]

74. Vinikoor, L.C.; Messer, L.C.; Laraia, B.A.; Kaufman, J.S. Reliability of variables on the North Carolina birth certificate: A comparison with directly queried values from a cohort study. Paediatr. Perinat. Epidemiol. 2010, 24, 102-112. [CrossRef]

75. Whitehead, T.P.; Metayer, C.; Wiemels, J.L.; Singer, A.W.; Miller, M.D. Childhood Leukemia and Primary Prevention. Curr. Probl. Pediatr. Adolesc. Health Care 2016, 46, 317-352. [CrossRef]

76. Danysh, H.E.; Mitchell, L.E.; Zhang, K.; Scheurer, M.E.; Lupo, P.J. Differences in environmental exposure assignment due to residential mobility among children with a central nervous system tumor: Texas, 1995-2009. J. Expo. Sci. Environ. Epidemiol. 2017, 27, 41-46. [CrossRef]

(C) 2019 by the authors. Licensee MDPI, Basel, Switzerland. This article is an open access article distributed under the terms and conditions of the Creative Commons Attribution (CC BY) license (http://creativecommons.org/licenses/by/4.0/). 